\title{
Myocardial protection during ischemia-reperfusion by remote preconditioning: a possible role of inducible nitric oxide synthase and glutathione peroxidase
}

\author{
Sandra M. Younan*, Mary A. Youssef*, Amal EL-Shehaby**, \\ Eman Obaia** \\ Departments of Physiology*, and Medical Biochemistry** \\ Faculty of Medicine, Cairo University
}

\begin{abstract}
Cardiac ischemia is considered to be one of the deleterious injury increasing the risk of cardiac morbidity and mortality. Remote protection of the heart via ischemiareperfusion of non-vital organs (Remote ischemic preconditioning RIPC) was suggested by many studies as one of the possible cardioprotective intervention. The aim of the present study was to examine the role of inducible nitric oxide synthase (iNOS) and glutathione peroxidase (GPx) in RIPC of the heart prior to ischemiareperfusion injury, and the possibility of protecting cardiac performance and reducing cardiac damage. Four groups of male rabbits $(n=10 /$ group $)$ were included in this study: Control sham operated group (group I); Remote ischemic preconditioning (RIPC) group (group II); ischemia-reperfusion (I/R) group (group III) and RIPC+I/R group (group IV). RIPC was performed in rabbits of group II and $I V$ by repeated four cycles of $10 \mathrm{~min}$ each of ischemia-reperfusion of femoral artery alternating with intervals of 10 minutes of reperfusion. After 24 hours, groups III and IV were subjected to 30 minutes pre-ischemic perfusion then 30 minutes of left coronary artery occlusion followed by 60 minutes of post-ischemic reperfusion. Serum creatine kinase (CK) was measured and the size of myocardial infarction was estimated at the end of the ischemic phase (as an index of myocardial ischemic injury). Glutathione peroxidase activity and mRNA iNOS expression were assessed in the cardiac tissue of the four groups. RIPC was found to have no significant effect on the left ventricular cardiac performance of normal heart. However, RIPC improved significantly the percentage recovery of the left ventricular developed pressure in group IV following ischemia-reperfusion compared to group III with no significant difference in the percentage recovery of both the contractility index and the heart rate. As regards glutathione peroxidase activity, it was significantly increased in group II compared to group I, and also as a consequence of cardiac ischemia reperfusion, GPx activity was significantly increased in group III compared to group I and II. RIPC and I/R increased significantly the GPX activity in group IV compared to other groups. Moreover, it was found that group IV had a significant increase in cardiac iNOS gene expression compared to group III, associated with a significant improvement of cardiac damage including serum creatine kinase and infraction size. Also, a significant positive correlation was found between GPx activity and iNOS gene expression in group IV. In conclusion, RIPC from skeletal muscles enhanced
\end{abstract}


the recovery of the heart developed pressure, reduced the post-ischemic CK level, reduced the myocardial infarction size and was accompanied by an increase of glutathione peroxidase activity and enhanced iNOS gene expression providing a possible potential target for the development of novel cardioprotective strategies during I/R injury.

Key words: Remote preconditioning, glutathione peroxidase, iNOS, and cardiac performance.

\section{INTRODUCTION}

Ischemic injury to vital organs such as the heart is an extremely common cause of morbidity and mortality ${ }^{(\mathbf{1})}$ Fortunately, preconditioning is one of the most powerful cardioprotective interventions identified and is also, by far, the most reproducible ${ }^{(2,3)}$. It consistently limits infarct size in every animal model and in every species examined, and there is considerable evidence that it is effective in protecting human myocardium, as well ${ }^{(4)}$.

Remote ischemic preconditioning (RIPC) presents an exciting clinical concept with the possibility that regional ischemia of non-vital tissue might protect remote organs. This would avoid the risks associated with inducing direct preconditioning in the vulnerable target organ.

Remote ischemic preconditioning was first described in the heart, where ischemic preconditioning (IPC) initiated in the vascular distribution of one coronary artery caused protection throughout the myocardium ${ }^{(5)}$. It was also proposed that protection from IPC can spread from distant organs such as intestine, kidney to the heart ${ }^{(6)}$. Many of the molecular and biochemical pathways responsible for the salubrious actions of remote preconditioning have been elucidated, providing potential targets for the development of novel cardioprotective strategies. Early remote preconditioning, which lasts for few hours, appears to be conducted through a pathway activated by the autonomic nervous system ${ }^{(6,7)}$, and/or humoral factors such as bradykinin, adenosine and opioids ${ }^{(7-10)}$. In addition to the early phase, RIPC can provide protection for up to 24 hours $^{(11)}$. Its prolonged time course is consistent with altered protein expression in the myocardium; this includes upregulation of proteins such as the different antioxidant enzymes and nitric oxide synthase (NOS $)^{(\mathbf{1 2})}$.

Inducible nitric oxide synthase (iNOS), as opposed to neuronal NOS (nNOS) and endothelial NOS (eNOS), is not constitutively expressed. Stimuli such as the proinflammatory cytokines, hypoxia and transactivation of the redox sensitive transcription factors nuclear factor kappa- $\beta$ (NFא$\beta)$ will induce $\mathrm{iNOS}^{(13)}$. It has been demonstrated that both ischemic PC and pharmacological PC upregulate iNOS, and that genetic ablation of iNOS activity results in abrogation of the beneficial effects of $\mathrm{PC}^{(14)}$.

Although several experimental studies have demonstrated the beneficial effects of $\operatorname{RIPC}^{(6,9,10,15)}$, fewer studies have so far failed to 
confirm the role of iNOS in RIPC ${ }^{(\mathbf{1 6})}$. At the same time many studies failed to demonstrate a protective role of iNOS during late $\mathrm{PC}^{(\mathbf{1 7})}$ and others even suggested a detrimental role in acute myocardial infarction ${ }^{(\mathbf{1 8 , 1 9 )}}$.

An increase in the formation of reactive oxygen species during ischemia-reperfusion and the adverse effects of oxyradicals on myocardium has been well established by both direct and indirect measurements ${ }^{\mathbf{( 2 0 )}}$. The three main antioxidant enzyme systems in the heart are superoxide dismutase (SOD), catalase, and glutathione peroxidase (GPx). In the myocardium, GPx may play a predominant role in the scavenging of $\mathrm{H}_{2} \mathrm{O}_{2}$. Catalase is the other major $\mathrm{H}_{2} \mathrm{O}_{2}$-scavenging enzyme. However, the activity of catalase in the heart is over 100-fold lower than its activity in the liver, another organ that contends with oxidative stress ${ }^{(\mathbf{1 5})}$. The balance between production of reactive oxygen species (ROS) and degradation of ROS by antioxidant substances is critical for the homeostasis of cardiac myocytes because of their dependence on aerobic metabolism.

The main objectives of the present study were firstly, to test the hypothesis that short periods of limb ischemia reperfusion can induce RIPC and reduce the infarct size that may be translated into a significant functional improvement; secondarily, to investigate a possible role for inducible nitric oxide synthase (iNOS) and glutathione peroxidase in adaptation of the rabbit heart to ischemia by remote, delayed protection which may resemble that of late IPC, and finally, to study a possible relation between cardiac iNOS and GPx activity.

\section{MATERIAL \& METHODS}

In the present study, male rabbits weighing (2000-3000 mg) were divided into groups $(\mathrm{n}=10 /$ group):

Group I (The control group): The rabbits were anesthetized by intraperitoneal injection of pentobarbitone $(35 \mathrm{mg} / \mathrm{kg}$ body weight ${ }^{(15)}$. Rabbits were sham operated through dissection of the femoral artery.

Group II (The preconditioned group): The rabbits were anesthetized as in group I. Then, the right femoral artery was exposed for performing RIPC by applying atraumatic vascular clamp to the artery for temporary total occlusion. RIPC was performed via four cycles; each cycle is formed of 10 minutes of ischemia followed by 10 minutes of reperfusion of the femoral artery. The occlusion was confirmed by collapse and no pulsation at the distal artery. The femoral artery was not occluded after the repetitive ischemia-reperfusion cycles $^{(21)}$.

Group III (The ischemia-reperfusion group): The rabbits were anesthetized as in group I, and the femoral artery was exposed. After 24 hours, the rabbits were subjected to 30 minutes pre-ischemic perfusion. After 30 minutes of stabilization, ischemia was induced by abolishing the left coronary artery flow from aerobic values $(11 \mathrm{ml} / \mathrm{min})$ to $0 \mathrm{ml} / \mathrm{min}$ for 30 minutes. The hearts were then reperfused for 60 minutes with a coronary flow of $11 \mathrm{ml} / \mathrm{min}^{(22)}$. 
Group IV (The preconditioned ischemia-reperfusion group): The rabbits were preconditioned as in group II, and after 24 hours, rabbits were subjected to ischemia/ reperfusion as in group III.

Mechanical performances of the left ventricle of the heart was determined by the systolic pressure, the diastolic pressure, the heart rate and the peak rate of maximum left ventricular pressure rise $(\mathrm{dp} / \mathrm{dt})$ difference in pressure-difference in time (index of contractility). These mechanical performances were monitored during the experiment by a balloon inserted into the left ventricle and connected to a polygraph apparatus (San-ei instrument LTD Nee, Tokyo, Japan). The developed pressure was calculated (systolic pressure -diastolic pressure).

Blood samples from retro-orbital vein and cardiac tissue samples were taken 24 hours from all groups.

\section{Measurement of creatine kinase:}

Serum creatine kinase was assessed by kit supplied by Sigma Aldrich, Milan, Italy.

Glutathione peroxidase activity:

About $0.5 \mathrm{~g}$ of cardiac tissue was dissected and was perfused with a phosphate buffer saline (PBS) solution $\mathrm{pH} 7.4$, and $0.16 \mathrm{mg} / \mathrm{ml}$ heparin, the tissue was homogenized in $5-10 \mathrm{ml}$ of cold buffer (i.e., $50 \mathrm{mM}$ Tris/ $\mathrm{HCl}, \mathrm{pH}$ 7.5, $5 \mathrm{mM}$ EDTA, and $1 \mathrm{mM}$ (DTT) dithiotheritol) per gram tissue, centrifuged at 10,000 for 15 minutes at $4{ }^{\circ} \mathrm{C}$. The supernatant was removed for glutathione peroxidase activity assay. GPx activity was measured using a coupled assay system. The oxidation of reduced glutathione was coupled to NADPH oxidation in a reaction catalyzed by glutathione reductase. A total of $500 \mu \mathrm{l}$ Tris $\mathrm{HCl}$ (0.2 mM/1, pH 8) was mixed with $100 \mu \mathrm{l}$ NADPH $(2 \mathrm{mM} / \mathrm{l})$ followed by $100 \mu \mathrm{EDTA}(5 \mathrm{mM} / \mathrm{l})$ and $100 \mu \mathrm{l}$ glutathione $(20 \mathrm{mM} / \mathrm{l})$. Homogenate samples $(100 \mu \mathrm{l})$ were then mixed with glutathione reductase (0.002 units) and incubated for $5 \mathrm{~min}$ at $37^{\circ} \mathrm{C}$ and for a further $5 \mathrm{~min}$ after the addition of $100 \mu \mathrm{l}$ of cumene hydroperoxide $(0.7 \mathrm{mM} / \mathrm{l})$. Absorbencies were read in a spectrophotometer at $340 \mathrm{~nm}^{\text {(23) }}$.

Determination of infarction size:

Part of the heart was taken for determination of the infarct size by $\mathrm{t}$ blue tetrazolium according to Vakeva et al. ${ }^{(24)}$.

Assessment of inducible nitric oxide synthase (iNOS) gene expression:

After decapitation, heart was rapidly excised and about $30 \mathrm{mg}$ of fresh cardiac tissue was homogenized in $175 \mu \mathrm{l}$ RNA lysis solution which contains guanidinum thiocyanate and $\beta$-mercaptoethanol and was centrifuged at $10.000 \mathrm{rpm}$ for $10 \mathrm{~min}$ at $4^{\circ} \mathrm{C}$. Then, the supernatants were kept frozen at $-80^{\circ} \mathrm{C}$ till examination for expression iNOS by RT-PCR. Total RNA was extracted from cardiac tissue using SV-total RNA isolation system (Promega Madison, USA) according to Chomeznski and Sacchi ${ }^{(25)}$. About $5 \mu \mathrm{g}$ of RNA was reverse transcribed and amplified using one step RT-PCR kit supplied by Qiagen (Valeneia, California, USA). Two primer sets were used; one for the target gene (iNOS) and the other for housekeeping gene (S18). Inducible NOS forward primer 5'CAG GAC CAC ACC CCC TCG GA-3' and reverse primer 5'-AGC CAC ATC CCG AGC CAT GC-3' 
were used, and the PCR product was 537 bp. Forward S18 primer 5'-AGG AAT TGA CGG AAG GGC AC-3' and reverse primer 5'-GTG CAG CCC CGG ACA TCT AAG-3' were used, and the PCR product was $324 \mathrm{bp}$. The PCR mixture contained $10 \mu \mathrm{l}$ of $10 \mathrm{x}$ PCR buffer, $2 \mu \mathrm{l}$ of $25 \mathrm{mM} \mathrm{MgCl}_{2}, 2$ $\mu \mathrm{l}$ of $10 \mathrm{mM}$ dNTPs mix, 2.5 units of Taq DNA polymerase and 100 pmol of each forward and reverse primers in a total volume of $100 \mu \mathrm{l}$. The mixture was processed for 40 cycles in a thermal cycler with the cycling parameters consisting of $94 \mathrm{C}^{\circ}$ for 1 $\min , 62 \mathrm{C}^{\circ}$ for $1 \mathrm{~min}$ and $72 \mathrm{C}^{\circ}$ for 1 min. Following the final cycle, an extension step of $10 \mathrm{~min}$ at $72 \mathrm{C}^{\circ}$ was performed $^{(\mathbf{2 6})}$. Ten $\mu \mathrm{l}$ volume of each PCR product was analyzed on a $2 \%$ agarose gel with ethidium bromide staining. The size of PCR products was compared with a DNA molecular size marker on ultraviolet transilluminater, and then Gel documentation was performed. PCR products were semi-quantitated by using gel documentation system (Bio Doc Analyze) supplied by Biometra.

\section{Statistical Analysis:}

The results were analyzed using SPSS computer software package, version 10.0 (Chicago-IL, USA) as described previously ${ }^{(27)}$. Data were presented as mean \pm standard deviation (SD). Differences among the three groups were compared by one-way ANOVA. To study the relationship between the variables, Pearson's correlation coefficient was calculated. The results were considered statistically significant at $\mathrm{p}$ $\leq 0.05$.

\section{RESULTS}

Table 1 shows the means \pm SD of left ventricular performance of the isolated hearts during the initial 30 minutes of perfusion in the studied groups. As revealed in table1, the RIPC of the hearts (groups II an IV) had no significant difference on the developed pressure, $\mathrm{dp} / \mathrm{dt}$, and heart rate compared to the corresponding parameters in sham operated groups (I and III). Moreover, RIPC had no significant difference on left ventricular performance of group II compared to those of group I after 2 hours of heart perfusion as shown in table 2. As observed in figure 1 , there was a significant increase in the developed pressure in group IV compared to group III $(\mathrm{p}<0.001)$. However, no significant difference was observed in $\mathrm{dp} / \mathrm{dt}$ and heart rate ( $p=0.09,0.07$; respectively) between group III and IV.

At the end of ischemiareperfusion, the infarction size was estimated and showed a significant decrease in group IV compared to group III. As shown in table 3, there was a significant increase in serum $\mathrm{CK}$ in group III and IV compared to group I and II $(p<0.001)$. It reached a highly significant increase in group III compared to other groups, but, group IV showed a highly significant decrease in CK compared to group III. While, no significant difference was observed between group I and II

As regards GPx activity, group II showed a significant increase in GPx activity compared to group I $(\mathrm{p}<$ $0.001)$. Also, there was a significant increase in GPx activity in group III and IV compared to group I. 
However, group III showed a significant decrease in GPx activity compared to group II and IV. Group IV showed a significant increase in GPx activity compared to group II and III.

Remote ischemic preconditioning in group II resulted in a significant increase in iNOS gene expression in cardiac tissue compared to group I. However, I/R in group III caused a significant decrease in iNOS gene expression compared to both group I and II. Moreover, RIPC before I/R injury in group IV resulted in a significant increase in iNOS gene expression compared to the other three groups.

Pearson correlation revealed absence of correlation between all parameters in group I and II. While, in group III there was a significant negative correlation between GPx and the infraction size $(r=-0.65, p=0.04)$. Also, in group IV, there was a significant positive correlation between the GPx activity and the iNOS gene expression $(r=0.67, \mathrm{p}=$ $0.03)$.

Table 1: Left ventricular performance in the studied groups during the initial 30 min. of perfusion

\begin{tabular}{|l|c|c|c|c|c|}
\hline \multicolumn{1}{|c|}{ Variables } & $\begin{array}{c}\text { Group I } \\
\text { (Control) }\end{array}$ & $\begin{array}{c}\text { Group II } \\
\text { (RIPC) }\end{array}$ & $\begin{array}{c}\text { Group III } \\
\text { (I/R) }\end{array}$ & $\begin{array}{c}\text { Group IV } \\
\text { (RIPC+ } \\
\text { I/R) }\end{array}$ & $\begin{array}{c}\text { p- } \\
\text { value }\end{array}$ \\
\hline $\begin{array}{l}\text { Developed } \\
\text { pressure }(\mathrm{mmHg})\end{array}$ & $108 \pm 13.2$ & $109.3 \pm 14.4$ & $95.4 \pm 9.5$ & $99.4 \pm 16$ & $\mathbf{0 . 0 7}$ \\
\hline $\mathrm{dp} / \mathrm{dt}(\mathrm{mmHg} / \mathrm{s})$ & $101.7 \pm 15.9$ & $101.6 \pm 15.9$ & $136.5 \pm 39.5$ & $110.2 \pm 35.4$ & $\mathbf{0 . 0 6}$ \\
\hline $\begin{array}{l}\text { Heart rate } \\
\text { (beats/min) }\end{array}$ & $123 \pm 14.8$ & $123.8 \pm 14.9$ & $130.4 \pm 17.1$ & $108.1 \pm 28.6$ & $\mathbf{0 . 0 9}$ \\
\hline
\end{tabular}

p-value is significant if $\leq 0.05^{*} \quad \mathrm{dp} / \mathrm{dt}$ : difference in pressure - difference in time

Table 2: Left ventricular performance in groups I and II after 2 hours of heart perfusion

\begin{tabular}{|l|c|c|c|}
\hline \multicolumn{1}{|c|}{ Variables } & $\begin{array}{c}\text { Group I } \\
\text { (Control) }\end{array}$ & $\begin{array}{c}\text { Group II } \\
\text { (RIPC) }\end{array}$ & p-value \\
\hline Developed pressure $(\mathrm{mmHg})$ & $75.9 \pm 1.4$ & $75.2 \pm 1.3$ & $\mathbf{0 . 3}$ \\
\hline $\mathrm{dp} / \mathrm{dt}(\mathrm{mmHg} / \mathrm{s})$ & $97.3 \pm 3.3$ & $97.7 \pm .3 .6$ & $\mathbf{0 . 8}$ \\
\hline Heart rate (beats $/ \mathrm{min})$ & $93.2 \pm 9.4$ & $92.2 \pm 9.6$ & $\mathbf{0 . 8}$ \\
\hline
\end{tabular}

$\mathrm{p}$-value is significant if $\leq 0.05^{*} \mathrm{dp} / \mathrm{dt}$ : difference in pressure - difference in time 
Table 3: Infarction size, creatine kinase and glutathione peroxidase activity in the studied groups

\begin{tabular}{|l|c|c|c|c|c|}
\hline \multicolumn{1}{|c|}{ Variables } & $\begin{array}{c}\text { Group I } \\
\text { (Control) }\end{array}$ & $\begin{array}{c}\text { Group II } \\
\text { (RIPC) }\end{array}$ & $\begin{array}{c}\text { Group III } \\
\text { (I/R) }\end{array}$ & $\begin{array}{c}\text { Group IV } \\
\text { (RIPC+I/R) }\end{array}$ & $\begin{array}{c}\text { p- } \\
\text { value }\end{array}$ \\
\hline $\begin{array}{l}\text { \% of } \\
\text { Infarction size }\end{array}$ & ---- & --- & $73.2 \pm 10.6$ & $41.6 \pm 13.84$ & $\mathbf{0 . 0 0 1}^{*}$ \\
\hline $\mathrm{CK}(\mathrm{U} / \mathrm{L})$ & $85.9 \pm 11.7^{\mathbf{a}}$ & $83.3 \pm 13.9^{\mathbf{a}}$ & $1585.6 \pm 216.9^{\mathbf{b}}$ & $314.57 \pm 58.09^{\mathbf{c}}$ & $\mathbf{0 . 0 0 1}^{*}$ \\
\hline $\begin{array}{l}\mathrm{GPx} \\
(\mathrm{nmol} / \mathrm{min} / \mathrm{ml})\end{array}$ & $257.7 \pm 49.6^{\mathbf{a}}$ & $615.8 \pm 194.1^{\mathbf{b}}$ & $379.1 \pm 82.6^{\mathbf{c}}$ & $933.8 \pm 252.7^{\mathbf{d}}$ & $\mathbf{0 . 0 0 1}^{*}$ \\
\hline $\begin{array}{l}\mathrm{iNOS}(\mu \mathrm{g} / \mathrm{g} \\
\text { tissue) }\end{array}$ & $378.9 \pm 88.1^{\mathbf{a}}$ & $748.9 \pm 114.8^{\mathbf{b}}$ & $547.2 \pm 97.6^{\mathbf{c}}$ & $858.4 \pm 102.6^{\mathbf{d}}$ & $\mathbf{0 . 0 0 1}^{*}$ \\
\hline
\end{tabular}

p-value is significant if $\leq 0.05^{*}$ Different symbols indicate significant difference CK: creatine kinase; GPx: glutathione peroxidase; iNOS: inducible nitric oxide synthase

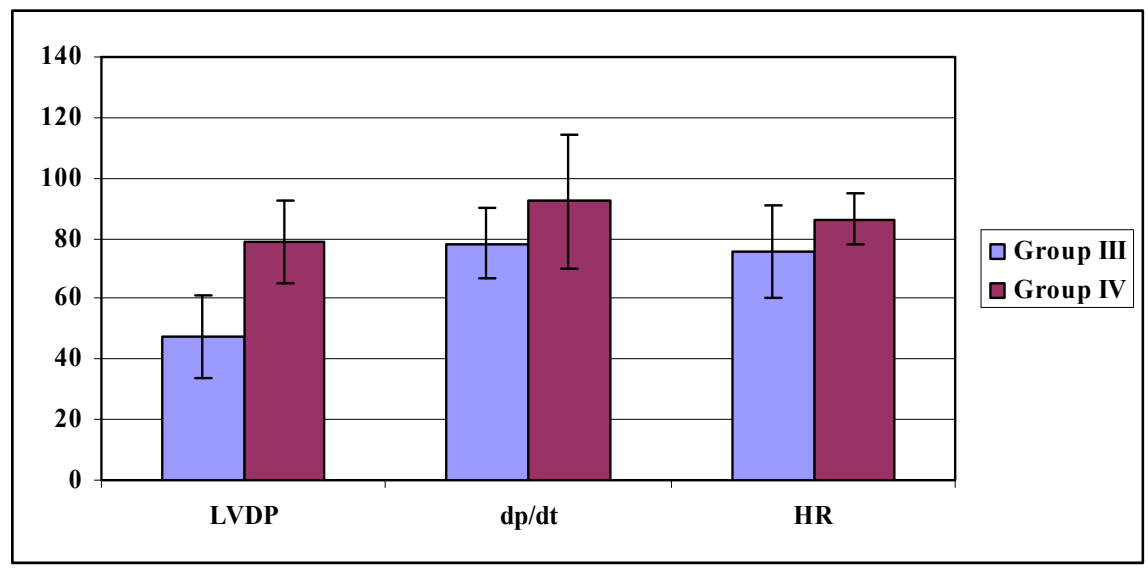

Figure 1: Left ventricular performance in groups III and IV after 2 hours of heart perfusion

LVDP: left ventricle developed pressure;

dp/dt: difference in pressure - difference in time;

HR: heart rate 


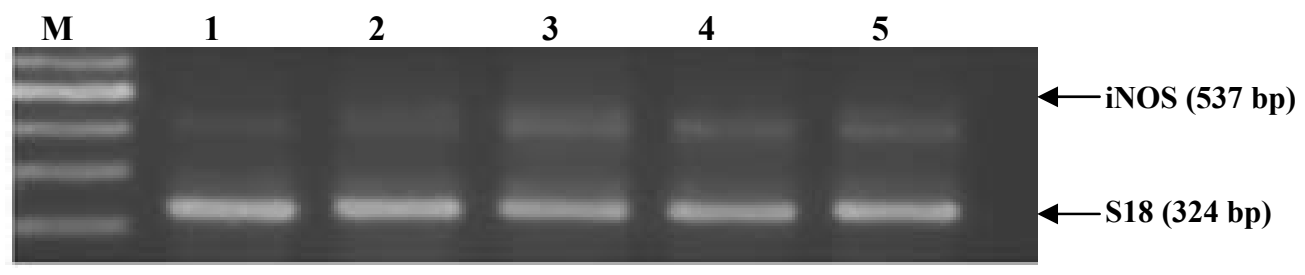

Figure 2: An agarose gel electrophoresis showing PCR product of iNOS and S18 in group I \&III

Lane M: PCR marker with 100 base pair ladder Lane 1 and 2: PCR product in group $I$ Lane 3, 4 and 5: PCR product in group III

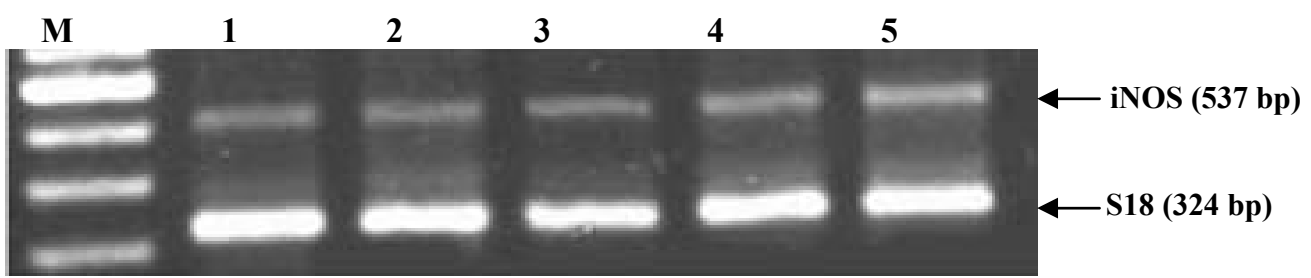

Figure 3: An agarose gel electrophoresis showing PCR product of iNOS and S18 in group II \&IV

Lane M: PCR marker with 100 base pair ladder

Lane 1, 2 and 3: PCR product in group II

Lane 4 and 5: PCR product in group IV

\section{DISCUSSION}

Ischemic preconditioning (IPC) has been explored widely in various experimental models ${ }^{(\mathbf{5 , 6})}$. More recently, a novel way to apply preconditioning has been described via remote organ ischaemia/ reperfusion (I/R) cycles (remote ischemic preconditioning RIPC) ${ }^{(\mathbf{2 8})}$. An added advantage is that in this way the entire heart may be preconditioned i.e. it is global, not regional ${ }^{(29)}$. Although cardiac protection by RIPC has been less extensively studied than local IPC, however, it has greater clinical applicability.
In the present study RIPC was performed in rabbits by repeated four cycles of $10 \mathrm{~min}$ each of ischemiareperfusion of femoral artery separated each by 10 minutes of reperfusion. The skeletal muscle was selected as the remote organ, as normal skeletal muscle is potentially an ideal tissue for the induction of remote preconditioning since it is inherently more resistant to ischemia than myocardial or neuronal cells, is capable of regeneration, and is readily accessible, although some controversial data still exist ${ }^{(28)}$.

The hemodynamic results obtained in the current study demonstrated that RIPC might have 
no significant effect on normal cardiac performance as evident by the non significant change obtained in the initial $30 \mathrm{~min}$ and at the end of cardiac perfusion between group II (RIPC group) and group I (control group). However, when ischemiareperfusion was performed in group III and IV, the effect of RIPC on the recovery of the LVDP (left ventricle diastolic pressure) was well apparent since a significant increase in postischemic $\%$ recovery of LVDP occurred in group IV (RIPC + I/R group) compared to group III (I/R group). These findings indicate that remote preconditioning has a stimulatory effect on the recovery of the heart developed pressure from I/R. Also, the percentage of recovery of both $\mathrm{dp} / \mathrm{dt}$ and heart rate were better in group IV compared to group III although such improvement was statistically insignificant.

Moreover, from the results of the present study it could be suggested that skeletal RIPC in rabbits is effective in protecting the myocardium from subsequent ischemia reperfusion injury by reduction of the infarction size and creatine kinase $(\mathrm{CK})$ enzyme released from the heart, since, the size of infarction and creatine kinase level were both reduced significantly in group IV compared to group III although both groups had eventually a significantly increased creatine kinase level compared to group I and II. These findings showed that the extent of myocardial infarction was significantly attenuated in the preconditioned group IV compared with the unpreconditioned group III when both were exposed to I/R injury.
Therefore, it may be possible to harness endogenous cardioprotection, triggered by ischemia of easily accessible tissues.

It is likely that reduction in myocardial infarct size in group IV compared to group III, although significant, was not of a great enough magnitude to induce a statistically significant protection against postischemic contractile dysfunction. In accordance with these findings, Jenkins et al. $^{(30)}$ and Yellon and Downey $^{(31)}$ had pronounced that in rabbit hearts, which do not contain xanthine oxidase, preconditioning had no effect on postischemic contractile function. Moreover, Kharbanda et al. ${ }^{(32)}$ had reported similar data in pigs and reported no significant effects of RIPC on the myocardial systolic functions but a trend of difference was detected regarding the myocardial diastolic functions improving the developed pressure. Although, Varadarajan et al. ${ }^{(33)}$ demonstrated that there was a greater contractile and relaxant effect after IPC in pigs. However, Sunderdiek et al. ${ }^{(34)}$ concluded that ischemic preconditioning in rabbits did not improve diastolic function during reperfusion. These conflicting data may be attributed to different mechanistic effects between IPC and RIPC otherwise the effects may be species specific.

The mechanisms by which the remote ischemic preconditioning stimulus exerts its effect has been attributed in previous studies to opioid receptors ${ }^{(35)}$, calcitonin gene-related peptide $^{(36)}, \quad$ iNOS $^{(11)}, \operatorname{eNOS}^{(37)}$, bradykinin $^{(7)}$, adenosine ${ }^{(8)}$, activation of ATP- sensitive $\mathrm{K}^{+}$channels ${ }^{(35)}$ or 
protein kinase $\mathrm{C}^{(\mathbf{6})}$. In addition to humoral and local myocardial factors, remote preconditioning may also involve the autonomic nervous system $^{(38)}$ or modulate the functions of circulating cells such as platelets ${ }^{(39)}$.

Regarding the proposed mechanism of RIPC, it was hypothesized in this study that the mechanisms underlying RIPC bears a great resemblance to that of IPC and since the effect of RIPC on cardiac gene expression is not fully understood, this study tested the hypothesis that RIPC modifies cardiac gene expression of inducible nitric oxide synthase (iNOS) and GPx activity.

The results of the present study demonstrated that RIPC is associated with enhanced cardiac GPx activity. RIPC of group II increased significantly GPx activity compared to control group I. This observation is of interest because there is in vivo evidence indicating that the cardiac glutathione peroxidase has a predominant protective role in the scavenging of $\mathrm{H}_{2} \mathrm{O}_{2}$, given that catalase, the other major $\mathrm{H}_{2} \mathrm{O}_{2}$ scavenging enzyme, shows a very low activity in the heart ${ }^{(\mathbf{1 5})}$. Also, it was reported that mice overexpressing GPx had reduced infarcts following focal cerebral ischemia, whereas the GPx knockout mouse showed an increased infarct ${ }^{(\mathbf{4 0})}$. The increased GPx activity, could be attributed to the adenosine, which is one of the predictable substances released from the remote ischemic tissue and was reported to protect the cardiovascular system from I/R injury ${ }^{(41)}$.

Moreover, there was a significant elevation of GPx activity in group III after I/R compared to group I although, it was significantly reduced compared to group II with a significant negative correlation between GPx and the infraction size in group III. The increase in GPx activity during I/R could be explained by the fact that GPx activity is enhanced by reactive oxygen species (ROS) and since reperfusion after brief ischemia is associated with a burst of ROS generation $^{(\mathbf{4 2})}$, it seems plausible to speculate that the increased oxidative stress could lead to an increase in antioxidant defenses in the myocardium.

Also, GPx activity in group IV (RIPC+ I/R) was significantly elevated in comparison to the other three groups. Thus, RIPC can provide protection to the myocardium through increased activity of GPx since the balance between production of reactive oxygen species (ROS) and degradation of ROS by antioxidant substances is critical for the homeostasis of cardiac myocytes because of their dependence on aerobic metabolism and although several studies have reported that antioxidant defenses are not upregulated during late $\mathrm{PC}^{(\mathbf{4 3})}$. The findings of this study demonstrate that late phase of RIPC may have different mechanisms compared to PC.

In fact nitric oxide has been emerged as a crucial modulator of myocardial preconditioning. Although NO derived from endothelial NO synthase (eNOS) is thought to be cardioprotective $^{(37)}$, the role of inducible NO synthase (iNOS) remains $\quad$ controversial $^{(\mathbf{1 8 , 4 4})}$. Furthermore, results have been controversial regarding which NOS is 
upregulated during late phase of preconditioning $^{(\mathbf{4 4 . 4 5})}$.

The current study showed that $\mathrm{RIPC}+\mathrm{I} / \mathrm{R}$ is associated with a significant increase in iNOS gene expression compared to other groups. The increase in cardiac iNOS gene expression found in this study was mild, far less than that observed in another study ${ }^{(46)}$ after a lethal dose of lipopolysaccharide. This supports the hypothesis that induction of iNOS after RIPC is protective because it is relatively modest, in contrast to other situations (such as inflammation or septic shock) in which iNOS induction is massive and promotes tissue injury ${ }^{(47)}$. The results of this study are consonant with the finding reported by other studies, in which they reported an increase in the cardiac iNOS gene expression after RIPC $^{(11,44)}$.

Thus, the results of present study propose that moderate enhancement of cardiac iNOS expression may be one of the possible signaling mechanisms underlying the protective effects of remote and late preconditioning since increased expression of iNOS in group IV was accompanied by an enhanced recovery of the cardiac hemodynamics following ischemiareperfusion, reduced $\mathrm{CK}$ level and reduced infarction size.

The precise mechanism(s) whereby RIPC leads to increased iNOS gene expression and subsequently to iNOS derived NO which can protect the heart against ischemia remains to be elucidated but according to previous studies ${ }^{(\mathbf{3 8})}$, It is possible that local triggers of RIPC released by the ischaemic tissue (including bradykinin and adenosine) activate the autonomic nervous system and/or a haemopoietic element ${ }^{(\mathbf{9 , 1 0})}$, transferring the signal to the myocardium (or other remote organ) that leads to activation of various kinases, e.g., protein kinase C- $\varepsilon$, tyrosine kinases, and mitogenactivated protein kinase, which activate transcription factors and then leads to myocardial gene transcription including iNOS, cyclooxygenase-2, and manganese superoxide dismutase ${ }^{(\mathbf{1 0 , 4 8 )}}$. Although, the exact role of iNOS-derived NO in cardiac protection is still unknown; several roles were suggested including: enhanced coronary perfusion (1), reduced myocardial oxygen consumption $^{(49)}$, enhanced ATPsensitive $\mathrm{K}^{+}$channel activity ${ }^{(50)}$, and inhibition of platelet adhesion to endothelial cells ${ }^{(51)}$.

On the other hand, other studies were in disagreement with the present study $^{(52,53,54)}$ they have concluded that iNOS exerts detrimental effects in the setting of myocardial infarction and suggested that activation of iNOS could have a negative effect on cardiac performance ${ }^{(53)}$. They have attributed this effect to the ability of iNOS to produce excessive amounts of NO, which reacts with the superoxide anion $\left(\mathrm{O}_{2}^{-}\right)$, generating the highly reactive oxidant peroxynitraite $\left(\mathrm{OONO}^{-}\right)$, they added that iNOS is capable of generating $\mathrm{O}_{2}{ }^{-}$ independently of $\mathrm{NO}$ production which leads to formation of $\mathrm{H}_{2} \mathrm{O}_{2}$. These two effects of iNOS increase the production of reactive oxygen species (ROS) that lead to further tissue damage ${ }^{(\mathbf{5 2}, 53,54)}$.

However, in the present study it was proposed that this detrimental 
effect can be obtained by massive induction of iNOS, which may not be the case in the current study. In such a way iNOS can serve diverse physiological functions. Moreover, the level of iNOS gene expression in this study was accompanied by increased GPx activity, which has a scavenging effect on $\mathrm{H}_{2} \mathrm{O}_{2}$ denoting another beneficial effect of RIPC. In addition the expressed iNOS gene did not interfere with the GPx activity as evident by the positive correlation between their levels in group IV, which is a controversial finding to the recently emerged evidence that GPx activity in myocytes is attenuated by elevated iNOS activity ${ }^{(\mathbf{5 5})}$.

In conclusion, a simple remote ischemic preconditioning from skeletal muscles performed $24 \mathrm{~h}$ before ischemia-reperfusion, enhanced the recovery of the heart developed pressure following $I / R$, reduced the post-ischemic CK level, reduced the myocardial infarction size and was accompanied by an increase of GPx activity and upregulation of iNOS gene expression. The function of iNOS in the cardiovascular system remains largely enigmatic and by using a rabbit model of RIPC, the present study provides new insights into the possible protective role against lethal ischemia/reperfusion injury, with a significant elevation of myocardial GPx activity.

\section{REFERENCES}

1. Burdess $A$ and Newby DE (2006): Harnessing the preconditioning phenomenon does remote organ ischemia provide the answer? Heart, 192(10): 1367-1378.

2. Bolli R (2006): The late phase of preconditioning. Circ.Res., 87: 972-983.

3. Cohen MV, Baines CP, Downey JM (2000): Ischemic preconditioning: from adenosine receptor of KATP channel. Annu.Rev.Physiol., 62: 79-109.

4. Bolli R, Becker L, Gross G, Mentzer R, Balshaw $D$, and Lathrop DA (2004): Myocardial protection at a crossroads. The need for translation into clinical therapy. Circ.Res., 95:125.

5. Przyklenk K, Bauer B, Ovize M, Kloner RA, and Whittaker $P$ (1993): Regional ischemic 'preconditioning' protects remote virgin myocardium from subsequent sustained coronary occlusion. Circulation, 87: 893899.

6. Wolfrum S, Schneider K, Heidbreder M, Nienstedt $\mathbf{J}$, Dominiak P, and Dendorfer $A$ (2002): Remote preconditioning protects the heart by activating myocardial PKC epsilon-isoform Cardiovasc.Res., 55: 583-589.

7. Schoemaker RG and van Heijningen CL (2000): Bradykinin mediates cardiac preconditioning at a distance. Am. J. Physiol. Heart. Circ. Physiol., 278: H1571-H1576.

8. Liem DA, Verdouw PD, Ploeg H, Kazim S, and Duncker DJ (2002): Sites of action of adenosine in interorgan preconditioning of the heart Am.J.Physiol.Heart.Circ.Physiol., 283: H29-H37. 
9. Dickson EW, Lorbar M, Porcaro WA, et al. (1999): Rabbit heart can be "preconditioned" via transfer of coronary effluent Am.J.Physiol., 277: H2451-H2457.

10. Dickson EW, Reinhardt CP, Renzi FP, Becker RC, Porcaro WA, and Heard SO (1999): Ischemic preconditioning may be transferable via whole blood transfusion preliminary evidence. J.Thromb.Thrombolysis, 8: 123129.

11. Wang Y, Xu H, Mizoguchi K, Oe $M$, and Maeta $H$ (2001): Intestinal ischemia induces late preconditioning against myocardial infarction a role for inducible nitric oxide synthase. Cardiovasc. Res., 49:391-398.

12. Pasupathy $S$ and HomerVanniasinkam S (2005): Ischaemic preconditioning protects against ischaemia/ reperfusion injury: emerging concepts. Eur. J. Vasc. Endovasc. Surgery, 29: 106-115.

13. Tokuno S (2001): Adaptation to ischemia with special emphasis on nitric oxide. Life sci., 91: 7323-7349.

14. Zhao T, Xi L, Chelliah J, Levasseur JE, and Kukreja RC (2000): Inducible nitric oxide synthase mediates delayed myocardial protection induced by activation of adenosine A1 receptors. Evidence from geneknockout mice. Circulation, 102: 902.

15. Chen Y, Chien C, Ma M, Tseng Y, Lin F, Wang $S$, and Chen C(2005): Protection "outside the box" (skeletal remote preconditioning) in rat model is triggered by free radical pathway. J. Surg. Res., 126: 92-101.

16. Nakano A, Heusch G, Cohen MV, and Downey JM (2001): Preconditioning one myocardial region does not necessarily precondition the whole rabbit heart. Basic. Res. Cardiol., 97: 35-39.

17. Xi L, Jarrett NC, Hess ML, Kukreja RC (1999): Myocardial Ischemia/reperfusion injury in the inducible nitric oxide synthase knockout mice. Life Sci; 65: 935945.

18. Sam F, Sawyer DB, Xie Z, Chang DL, Ngoy S, Brenner DA, Siwik DA, Singh K, Apstein CS, and Colucci W (2001): Mice lacking inducible nitric oxide synthase have improved left ventricular contractile function and reduced apoptotic cell death late after myocardial infarction. Circ.Res., 89: 351.

19. Feng Q, Lu X, Jones DL, Shen J, and Arnold MO (2001): Increased inducible nitric oxide synthase expression contributes to myocardial dysfunction and higher Mortality after myocardial infarction in mice. Circulation, 104: 700 .

20. Kevin LG, Camara AK, and Ries (2003): Ischemic preconditioning alters real-time measure of oxygen radicals in intact heart with ischemia and reperfusion. Am.J.Physiol., 284: H566-573.

21. Oxman Y, Arad M, Klein R, Avazov N, and Rabinowitz B (1997): Limb ischemia 
preconditions the heart against reperfusion tachyarrhythmia. Am.J.Physiol; 273: H1707.

22. Sett SS, TearI $H$, and LeBlanc JG (1997): Effect of glutamateaspartate on post-ischemic neonatal myocardium. Thorac. ardiovasc. urg., 13:462-6.

23. Avissar N, Slemmon JR, Palmer IS, and Cohen HJ (1991): Partial sequence of human plasma GPx and immunologic identification of milk glutathione peroxidase as the plasma enzyme. J.Nutr., 121:1243-1249, 1991.

24. Vakeva AP, Agah A, and Scott A (1998): Myocardial infarction and apoptosis after myocardial ischemia and reperfusion. Circulation, 97: 2259-2267.

25. Chomeznski $P$ and Sacchi $C$ (1987): Single step method of RNA isolation by guanidium thiocyanate-phenol chloroform extraction. Anal.Biochem., 162: 156-159.

26. Okawa T, Asano K, Takahashi H, Hashimoto S, Anbe H, Sato $A$, and Gafield RE (2004): Expression of iNOS mRNA and inhibitory effect of NO on uterine contractile activity in rats are determined by local rather than systemic factors of pregnancy. J.Pharmacol. Sci., 93: 349-354.

27. Norusis MJ (1997): SPSS 7.5 guide to data analysis, Simon and Schuster Company, Upper Saddle river .New Jersey.

28. Heusch $G$ and Schulz $S$ (2002): Remote preconditioning. J. Mol. Cell.Cardiol., 34: 1279-81.

29. Birnbaum Y, Sharon LH, and Kloner RA (1997): Ischemic preconditioning at a distance: reduction of myocardial infarct size by partial reduction of blood supply combined rapid stimulation of the gastrocnemius muscle in the rabbit. Circulation, 96: 1641-1657.

30. Jenkins DP, Pugsley WB, and Yellon DM (1995): Ischemic preconditioning in a model of global ischemia: infarct size limitation, but no reduction of stunning. J.Mol.Cell.Cardiol., 27: 1623-1632.

31. Yellon DM and Downey JM (2003): Preconditioning the Myocardium: From Cellular Physiology to Clinical Cardiology. Physiol. Rev., 83: 1113-1151.

32. Kharbanda RK, Li J, Konstantinov I, Cheung M, White P, Frndova H, Stokoe J, Cox P, Vogel M, Van Arsdell G, MacAllister R, and Redington A (2006): Remote ischemic preconditioning protects against cardiopulmonary bypass induced tissue injury-a preclinical study. Heart, 92(10): 1056-1061.

33. Varadarajan SG, Novalija E, and Stowe DF (2001): Ischemic and anesthetic preconditioning reduces cytosolic $\left[\mathrm{Ca}^{+2}\right]$ and improves $\mathrm{Ca}^{+2}$ responses in intact hearts. Am. J. Physiol. Heart. Circ. Physiol., 281: H1508H1523.

34. Sunderdiek U, Schmitz-Spanke S, Korbmacher B, Gams E, and Schipke J (2001): Left ventricular dysfunction and disturbed $\mathrm{O}_{2}$-utilization in stunned myocardium: influence of ischemic preconditioning. Eur. 
J. Cardiothorac.Surg., 20: 770776 .

35. Dickson EW, Tubbs RJ, and Porcaro WA (2002): Myocardial preconditioning factors evoke mesenteric ischemic tolerance via opioid receptors and $\mathrm{K}$ (ATP) channels. Am. J. Physiol. Heart. Circ. Physiol., 283:H22-H28.

36. Hu CP, Peng J, Xiao L, Ye F, Deng HW, and Li Y (2002): Effect of age on alpha-calcitonin gene related peptide-mediated delayed cardioprotection induced by intestinal preconditioning in rats Regul. Pept., 107: 137-143.

37. Jones SP, Greer JJ, Kakkar AK, Ware PD, Turnage RH, Hicks M, van Haperen R, de Crom R, Kawashima S, Yokoyama M, and Lefer DJ (2004): Endothelial nitric oxide synthase overexpression attenuates myocardial reperfusion injury. Am. J. Physiol. Heart. Circ. Physiol., 286: H276-282.

38. Loukogeorgakis SP, Panagiotidou AT, Broadhead MW, Donald A, Deanfield JE, and MacAllister RJ (2005): Remote ischemic preconditioning provides early and late protection against endothelial ischemia-reperfusion injury in humans. Role of the autonomic nervous system. J.Am.Coll.Cardiol., 46: 450-456.

39. Hata $K$, Whittaker $P$, and Kloner RA (1999): Brief myocardial ischemia attenuates platelet thrombosis in remote, damaged, and stenotic carotid arteries. Circulation, 100: 843848.

40. Crack PJ, Taylor JM, Flentjar NJ, de Haan J, Hertzog P,
Iannel RC, and Kola I (2001): Increased infarct size and exacerbated apoptosis in the glutathione peroxidase-1 (Gpx-1) knockout mouse brain in response to ischemia/reperfusion injury, J.Neurochem., 78:1389-1399.

41. Zhang Y, Handy ED, and Loscalzo J (2005): Adenosinedependent induction of glutathione peroxidase-1 in human primary endothelial cells and protection against oxidative stress. Circ.Res., 96: 831.

42. Dhalla NS, Elmoselhi AB, Hata T, and Makino N (2000): Status of myocardial antioxidants in ischemia-reperfusion injury. Cardiovasc.Res., 47: 446-456.

43. Tang XL, Qiu Y, Turrens JF, Sun JZ, and Bolli R (1997): Late preconditioning against stunning is not mediated by increased antioxidant defenses in conscious pigs. Am. J. Physiol. Heart. Circ. Physiol., 273: H1651-H1657.

44. Li G, Labruto F, Sirsjö A, Chen F, Vaage $J$, and Valen $G$ (2004): Myocardial protection by remote preconditioning: the role of nuclear factor kappa-B p105 and inducible nitric oxide synthase. Eur.J.Cardiothorac.Surg., 26 : 968-973.

45. Xuan YT, Tang XL, Qiu Y, Banerjee S, Takano H, Han H, and Bolli $R$ (2000): Biphasic response of cardiac NO synthase isoforms to ischemic preconditioning in conscious rabbits. Am. J. Physiol. Heart. Circ. Physiol., 279: H2360-2371.

46. Zhang C, Walker LM, Hinson JA, and Mayeux PR (2000): Oxidant stress in rat liver after 
lipopolysaccharide

administration: Effect of inducible nitric-oxide synthase inhibition. J. Pharm. Exp. Therp., 293, 968-972.

47. Lortie MJ, Ishizuka S, Schwartz D, and Blantz RC (2000): Bioactive products of arginine in sepsis: tissue and plasma composition after LPS and iNOS blockade. Am. J. Physiol. Cell. Physiol., 278: C1191-C1199.

48. Imagawa, J, Yellon DM, and Baxter GF (1999): Pharmacological evidence that inducible nitric oxide synthase is a mediator of delayed preconditioning. $\mathrm{Br}$. Pharmacol., 126: 701-708.

49. Shinmura K, Xuan YT, Tang XL, Kodani E, Han H, Zhu Y, and Bolli $R$ (2002): Inducible nitric oxide synthase modulates cyclooxygenase- 2 activity in the heart of conscious rabbits during the late phase of ischemic preconditioning. Circ.Res., 90: 602.

50. Kristiansen SB, Henning O, Kharbanda RK, Nielsen-Kudsk JE, Schmidt MR, Redington AN, Nielsen TT, and Botker HE (2005): Remote preconditioning reduces ischemic injury in the explanted heart by a $\mathrm{K}^{+}$-ATP channel-dependent mechanism. Am. J. Physiol. Heart. Circ. Physiol., 288: H1252-6.
51. Cerwinka WH, Cooper D, Krieglstein CF, Feelisch $M$, and Granger DN (2002): Nitric oxide modulates endotoxin-induced platelet-endothelial cell adhesion in intestinal venules. Am. J. Physiol. Heart. Circ. Physiol., 282: H1111-H1117.

52. Calderone A (2003): "The therapeutic effect of natriuretic peptides in heart failure; differtial regulation of endothelial and inducible nitric oxide synthase." Heart Fail.Rev., 8: 55-70.

53. Sun $Y$, CarreteroOA, $X u J$ Rhaleb NE, Wang F, Lin C, Yang JJ ,Pagano PJ, and Yang XP (2005): Lack of inducible NO synthase reduces oxidative stress and enhances cardiac response to isoproternol in mice with deoxycorticosterone. Acetate-salt hypertension. Hypertension, 46: 1355.

54. Wang D, Yang XP, Liu YH, Carretero OA, and LaPointe MC (1999): Reduction of myocardial infarct size by inhibition of inducible nitric oxide synthase. Am.J.Hypertens., 12: 174-182.

55. Nilakantan $V$, Zhou $X$, Hilton G, Roza AM, Adams MB, Johnson CP, and Pieper GM (2005): Hierarchical change in antioxidant enzyme gene expression and activity in acute cardiac rejection: role of inducible nitric oxide synthase. Mol. Cell. Biochem., 270: 39-47. 


\title{
الدورالمحتمل للجلوتاسيون بيروكسيديز و صاتع أكسيد النيتريك المستحث فى المي حماية القلب من فقز الام الموضعى و الحقن المتواصل
}

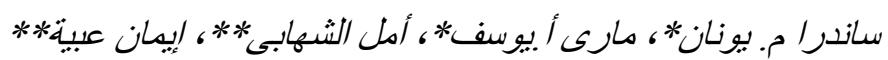

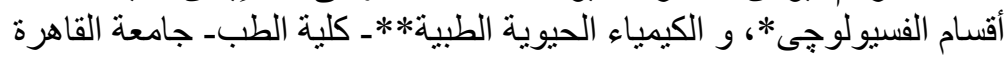

يعتبر فقر الدم الموضعى للقلب واحداً من أكثر الأضرار التى تصيب القلب و تزيد من خطر

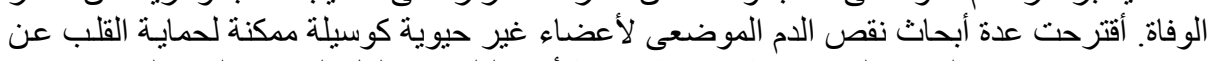

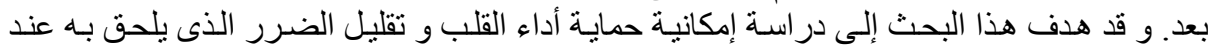

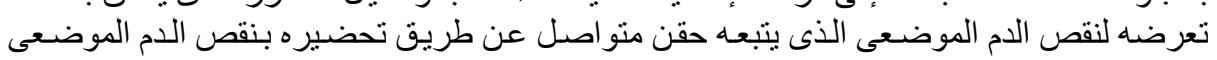

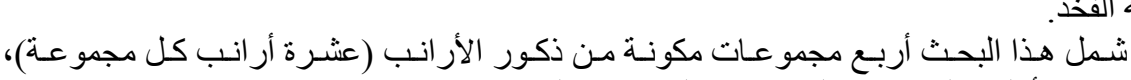
لعضلة الفخذ الفئ.

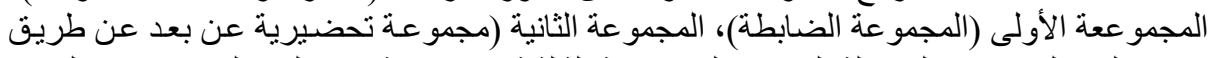

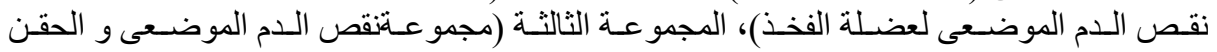

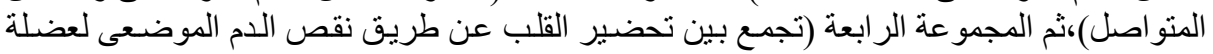

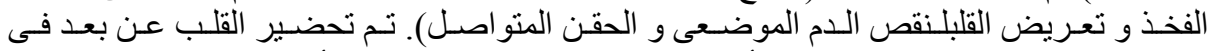

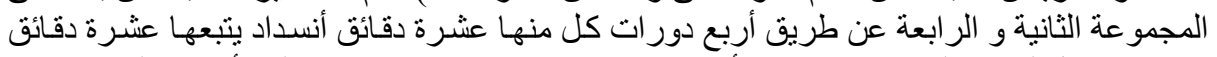

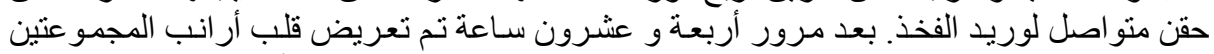

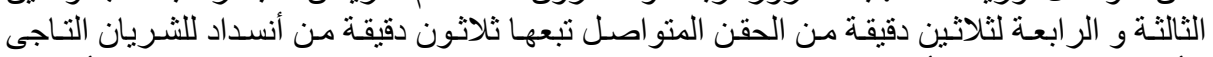

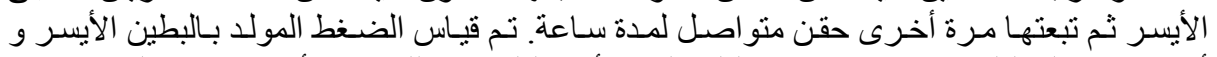

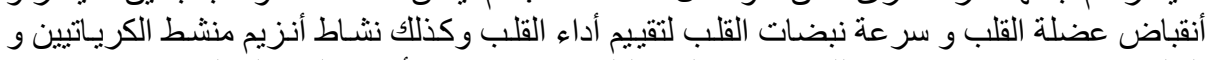

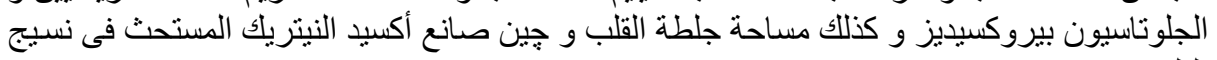
القلب.

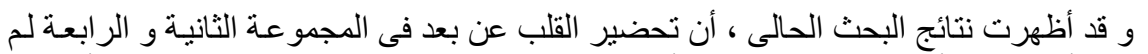

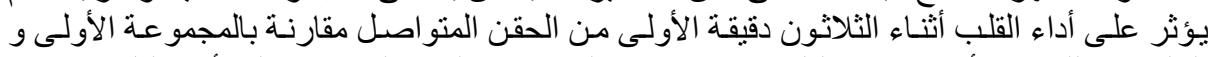

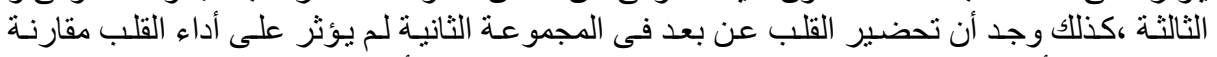

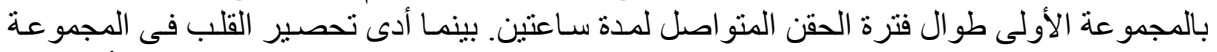

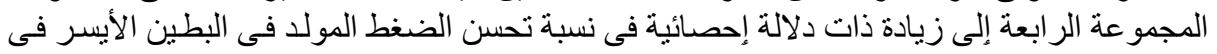

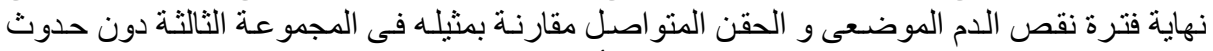

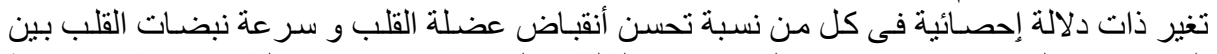

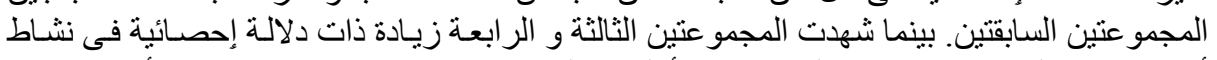

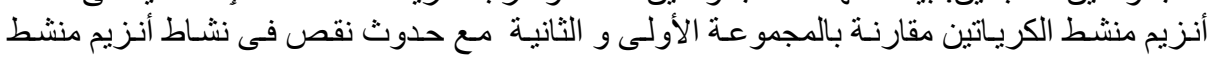

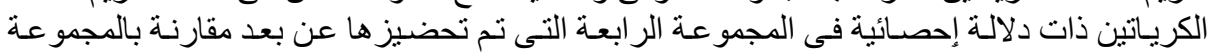

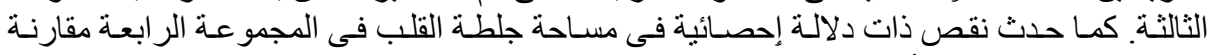

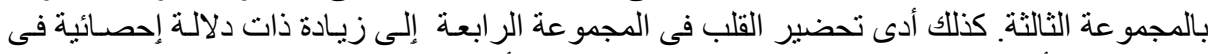

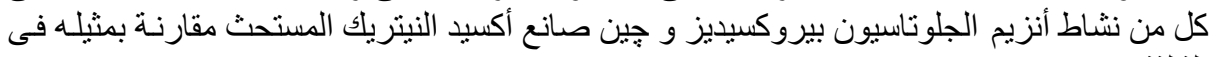
الثالثة.

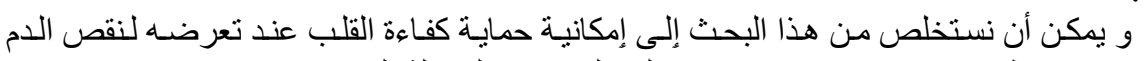
الموضعى عن طريق تحضيره عن بعد بنقص الدم الموضعى لعضلة الفذذا. 